FitzGerald, A. M., D. M. Whitaker, J. Ralston, J. J. Kirchman, and I. G. Warkentin. 2017. Taxonomy and distribution of the imperilled Newfoundland Gray-cheeked Thrush, Catharus minimus minimus. Avian Conservation and Ecology 12(1):10. https://doi.org/10.5751/ ACE-00976-120110

Copyright (C) 2017 by the author(s). Published here under license by the Resilience Alliance.

Research Paper

\title{
Taxonomy and distribution of the imperilled Newfoundland Gray- cheeked Thrush, Catharus minimus minimus
}

\author{
Alyssa M. FitzGerald ${ }^{1,2}$, Darroch M. Whitaker ${ }^{3}$, Joel Ralston ${ }^{4}$, Jeremy J. Kirchman ${ }^{2}$ and Ian G. Warkentin ${ }^{5}$ \\ ${ }^{1}$ Ecology and Evolutionary Biology, State University of New York, Albany, NY, USA, ${ }^{2}$ New York State Museum, Albany, NY, \\ USA, ${ }^{3}$ Parks Canada, ${ }^{4}$ Department of Biology, Saint Mary's College, Notre Dame, IN, USA, ${ }^{5}$ Environmental Science, Memorial \\ University of Newfoundland, Corner Brook, NL, Canada
}

\begin{abstract}
Gray-cheeked Thrushes breeding on Newfoundland are purported to be a distinct subspecies (Catharus minimus minimus) and have declined precipitously since the 1980s. To assess the validity of Gray-cheeked Thrush subspecies we collected blood samples and morphological measurements from 51 individuals captured at 15 sites in Newfoundland and Labrador (2013-2015). Analysis of mitochondrial (ND2) and nuclear intron (ADAM-TS 6, FIB7) sequences from these and additional samples from Nova Scotia, Newfoundland, Labrador, Quebec, Alaska, and Siberia showed low genetic variation at both nuclear loci, and shallow mitochondrial divergence between subspecies; there were no shared haplotypes between thrushes from Newfoundland / Nova Scotia $(\mathrm{n}=41)$ and those from western Labrador and further west $(\mathrm{n}=24)$. Thrushes from Newfoundland also had shorter wing chords, tails, and culmens and less black in the mandible compared to those from western Labrador and Quebec. Samples from the southeast coast of Labrador $(\mathrm{n}=13)$ included ND2 haplotypes both from Newfoundland and western Labrador plus one putative hybrid that was phenotypically a Gray-cheeked Thrush but that had a Bicknell's Thrush $(C$. bicknelli) ND2 haplotype and was heterozygous at a segregating site in FIB7. We detected thrushes during point counts at 7 of 24 sites on Newfoundland, but failed to detect them at 10 historically occupied sites on Newfoundland or in the reported distribution gap between subspecies in Labrador. Sites where thrushes have apparently disappeared had less shrub habitat within $1250 \mathrm{~m}$ and more large broadleaf trees within territory-scale areas compared to sites where they persist. Additionally, red squirrels (Tamiasciurus hudsonicus) are an introduced species on Newfoundland and thrush occurrence was $>3 x$ higher at sites where red squirrels were not detected. Our results support previous designations of $C$. $m$. minimus from Newfoundland and southeastern Labrador as a subspecies distinct from C. m. aliciae found further west.
\end{abstract}

\section{Taxonomie et répartition de la Grive à joues grises de Terre-Neuve, Catharus minimus minimus, en péril}

RÉSUMÉ. Les Grives à joues grises qui nichent sur l'île de Terre-Neuve sont considérées comme une sous-espèce distincte (Catharus minimus minimus) et ont nettement diminué depuis les années 1980. Afin d'évaluer s'il s'agit d'une véritable sous-espèce, nous avons collecté des échantillons sanguins et pris des mesures morphologiques sur 51 individus capturés à 15 sites à Terre-Neuve et au Labrador (2013-2015). L'analyse des séquences mitochondriale (ND2) et d'introns nucléaires (ADAM-TS 6, FIB7) de ces échantillons ainsi que d'autres récoltés en Nouvelle-Écosse, à Terre-Neuve, au Labrador, au Québec, en Alaska et en Sibérie, a montré une faible variation génétique aux deux locus nucléaires et une divergence mitochondriale peu prononcée entre les sous-espèces; nous n'avons pas trouvé d'haplotypes communs entre les grives de Terre-Neuve/Nouvelle-Écosse $(n=41)$ et celles de l'ouest du Labrador ou plus à l'ouest $(\mathrm{n}=$ 24). Les grives de Terre-Neuve avaient aussi des ailes, une queue et un culmen plus courts et arboraient moins de noir dans la mandibule comparativement aux grives de l'ouest du Labrador et du Québec. Les échantillons provenant de la côte sud-est du Labrador $(\mathrm{n}=13)$ comprenaient des haplotypes ND2 de Terre-Neuve et de l'ouest du Labrador, en plus d'un hydride possible qui présentait le phénotype d'une Grive à joues grises mais avait l'haplotype ND2 d'une Grive de Bicknell ( . bicknelli) et était hétérozygote à un site de ségrégation sur FIB7. Nous avons détecté des grives à des points d'écoute à 7 des 24 sites à Terre-Neuve, mais n'avons pas réussi à les détecter à 10 sites occupés dans le passé à Terre-Neuve ni dans le territoire reconnu comme inoccupé entre les aires des sous-espèces au Labrador. Les sites où les grives ont apparemment disparu présentaient moins de milieux arbustifs dans un rayon de $1250 \mathrm{~m}$ et plus de gros arbres feuillus à l'échelle du territoire comparativement aux sites où les grives sont toujours présentes. De plus, l'écureuil roux (Tamiasciurus hudsonicus) est une espèce introduite sur Terre-Neuve et l'occurrence des grives était plus de trois fois plus élevée aux sites où aucun écureuil n'a été détecté. Nos résultats corroborent les désignations antérieures de C. m. minimus à Terre-Neuve et au sud-est du Labrador en tant que sous-espèce distincte de $C$. m. aliciae, trouvée plus à l'ouest.

Key Words: distribution; endemism; genetics; habitat; hybrid; Gray-cheeked Thrush; Labrador; Newfoundland; red squirrel; subspecies; taxonomy 


\section{INTRODUCTION}

Newfoundland is the largest island in the circumpolar taiga biome and one of the 20 largest islands in the World. Despite its proximity to mainland North America, Newfoundland supports a moderate degree of landbird endemism and at least 24 insular subspecies have been proposed through morphometric studies (e.g., Peters and Burleigh 1951, Montevecchi and Tuck 1987). Molecular genetics analyses have supported and enhanced our understanding of endemism on Newfoundland, indicating that both resident species such as Rock Ptarmigan (Lagopus mutus welchi; Holder et al. 2004), Boreal Chickadee (Poecile hudsonicus rabbittsi; Lait and Burg 2013), and Gray Jay (Perisoreus canadaensis sanfordi; van Els et al. 2012, Dohms 2016), and Neotropical migrants including American Redstart (Setophaga ruticilla; Colbeck et al. 2008) and Blackpoll Warbler (Setophaga striata; Ralston and Kirchman 2012) have genetically distinctive populations. Although endemism on Newfoundland is undoubtedly maintained by contemporary marine barriers, the population structure for many of these species may have originated through historical isolation in Pleistocene glacial refugia, including the putative Atlantic Shelf refugium on the now submerged continental shelf south and east of Newfoundland (Rogerson 1983, Pielou 1991, Jaramillo-Correa et al. 2004, van Els et al. 2012, Lait and Burg 2013).

The Gray-cheeked Thrush (Catharus minimus) is a Neotropical migrant songbird that breeds in northern boreal forests from Newfoundland to Alaska in North America and across the Bering Sea to eastern Siberia. It is characteristically associated with dense conifer and broadleaf shrub thickets, and its breeding range extends north of the treeline into low Arctic willow and alder beds (Lowther et al. 2001). The early nomenclature of Gray-cheeked Thrushes was unstable as taxonomists struggled to identify affinities among specimens collected on breeding, migrating, and wintering grounds. However, following the description of "Bicknell's Gray-cheeked Thrush" (Ridgway 1882), a consensus emerged that the species comprised two subspecies: a larger, grayer form that bred from Siberia to Newfoundland, and a smaller, browner form that bred from Nova Scotia to New York (Ridgway 1907, Hellmayr 1934). Wallace (1939) was the first to describe the subtle differences in coloration that distinguish the Newfoundland birds, which he found to be similar in size to the continental form Hylocichla minima aliciae but with distinctly browner backs like those of $H . m$. bicknelli. Thus, he recognized three geographic groups: (1) the Northern Gray-cheeked Thrush, breeding from Labrador to Siberia; (2) the Newfoundland Gray-cheeked Thrush, breeding on insular Newfoundland; and (3) Bicknell's Graycheeked Thrush, breeding in montane and coastal forests of Nova Scotia, New Brunswick, southern Quebec, and the northeastern United States. Marshall (2001) also noted the intermediate size and coloration of Gray-cheeked Thrushes breeding on Newfoundland and suggested that in the past they may have intergraded with Bicknell's Thrushes along the north shore of the Gulf of St. Lawrence. Following Ouellet (1993), Bicknell's Thrush was recognized as a separate species (Catharus bicknelli) based on morphology, vocalizations, and genetic differences (Monroe et al. 1995, AOU 1998, Rimmer et al. 2001, Dickinson and Christidis 2014). However, treatment of the Northern and Newfoundland Gray-cheeked Thrush groupings is not consistent, with some referring to them as distinct subspecies (e.g., Godfrey 1986, Ouellet 1996, Lowther et al. 2001, Dickinson and Christidis 2014), and others interpreting the differences between these two groups as representing a cline within a single monotypic species (Wallace 1939, Marshall 2001).

Various lines of evidence support the split of Northern (C. $m$. aliciae) and Newfoundland (C. m. minimus) groupings into distinct subspecies. Northern Gray-cheeked Thrushes are larger, have olive-gray upper parts and flanks, a light cream-washed breast, and have a minimal extent of pale greyish-pink or dull yellow at the base of the lower mandible. In contrast, Newfoundland Gray-cheeked Thrushes average slightly smaller, and have olive-brown upperparts, grayish-brown to brownisholive flanks, chestnut edging on the remiges in some individuals, a cream or buffy colored breast, and a more extensive and typically brighter yellow-toned base to the lower mandible (Lowther et al. 2001, Marshall 2001). There may also be song differences between Northern and Newfoundland Gray-cheeked Thrushes (Marshall 2001). Finally, distributional surveys (Todd 1963, Quebec Breeding Bird Atlas 2016) suggest that there is a gap in Graycheeked Thrush occurrence between the north shore of the Gulf of St. Lawrence (including southeastern Labrador) and central Labrador, implying that the breeding ranges of the Northern and Newfoundland subspecies are allopatric.

Habitat use may also differ between Northern and Newfoundland Gray-cheeked Thrushes. Whereas the Northern subspecies favors dense, low stature coniferous and deciduous thickets across its range (Todd 1963, Godfrey 1986, Kessel 1998, Lowther et al. 2001, Marshall 2001), Gray-cheeked Thrushes on Newfoundland appear to make more limited use of deciduous thickets, and instead are characteristically associated with windswept coastal conifer thickets, conifer scrub, regenerating clearcuts dominated by young balsam fir (Abies balsamea), and high elevation, oldgrowth balsam fir forests (Lamberton 1976, Vassallo and Rice 1981, Thompson et al. 1999, Marshall 2001, Whitaker et al. 2015). These latter elements suggest habitat affinities similar to those of Bicknell's Thrushes (Rimmer et al. 2001). The island of Newfoundland, which falls within the Boreal Softwood Shield Bird Conservation Region (BCR8; Bird Studies Canada and NABCI 2014), is also the only extensive portion of the Graycheeked Thrush breeding range typified by southern boreal vegetation types.

Recent concern over a dramatic decline in Gray-cheeked Thrush numbers on Newfoundland has increased the importance of clarifying the taxonomic status of individuals breeding on the island (SSAC 2010). Prior to 1984, 30\% of Breeding Bird Surveys (BBS; Sauer et al. 2014) on Newfoundland recorded 10 or more thrushes per 50 -stop route (overall mean $=9.04$ thrushes per route; maximum $=38$ ). However no BBS survey has recorded more than three thrushes since 1988 and overall encounter rates have declined by $\sim 95 \%$ (SSAC 2010; see also Environment Canada 2014). Consequently C. m. minimus is now listed as threatened under the Newfoundland and Labrador Endangered Species Act. BBS data indicate that Northern Gray-cheeked Thrushes in Alaska and possibly mainland Canada are also declining, though estimated trends are much weaker than on Newfoundland (SSAC 2010, Environment Canada 2014, Sauer et al. 2017). This suggests that both pandemic stressors, e.g., degradation of wintering habitat, and factors specific to the island of Newfoundland may be affecting the species (SSAC 2010). 
Fig. 1. Population samples and ND2 haplotype network for Gray-cheeked Thrushes (Catharus minimus; $\mathrm{n}=$ 77). (A) Circles denote locations and sizes of samples; ellipses denote regional groupings for pairwise $\varphi s t$ analysis. The dotted lines represent the putative range gap between thrush subspecies. The inset map shows the breeding range of Gray-cheeked Thrush (dark gray). (B) Minimum spanning haplotype network of 77 ND2 sequences (1041 base pairs), where each tic mark along branches equals one nucleotide substitution. Twelve individuals from southern Labrador are illustrated in grey, half of which cluster with thrushes from western Labrador (black) and the other half of which cluster with those from Newfoundland (white).

Samples from Alaska $(n=7)$ and Siberia $(n=3)$ are included in the haplotype network (black) but are not illustrated on the map.

(A)

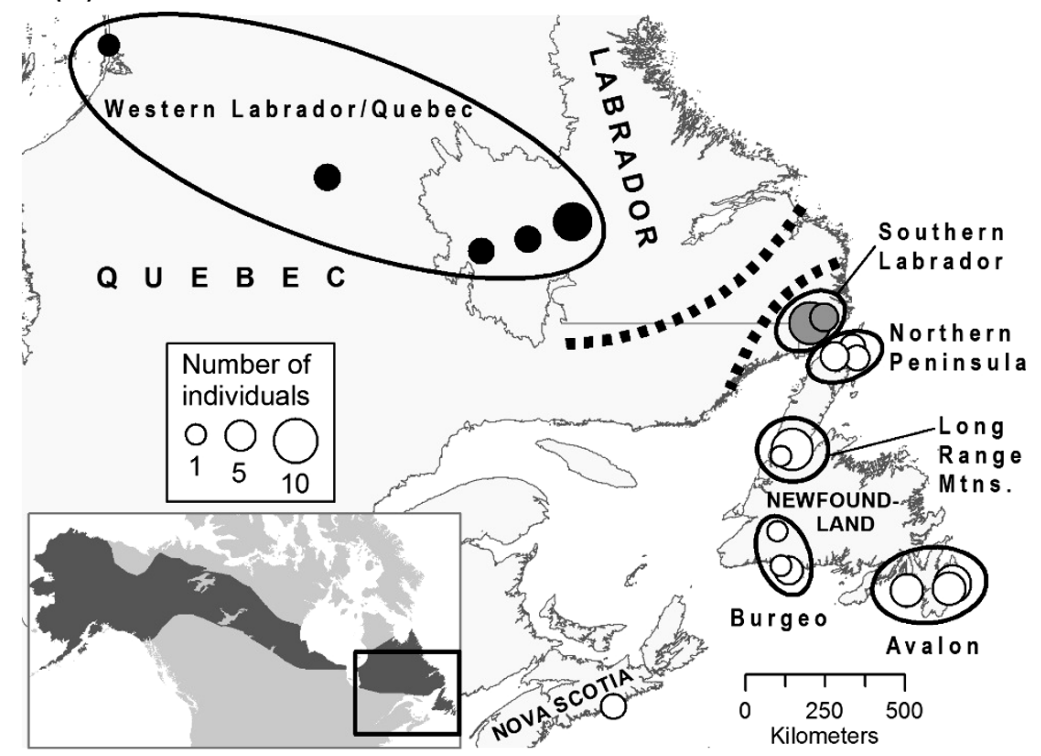

(B)

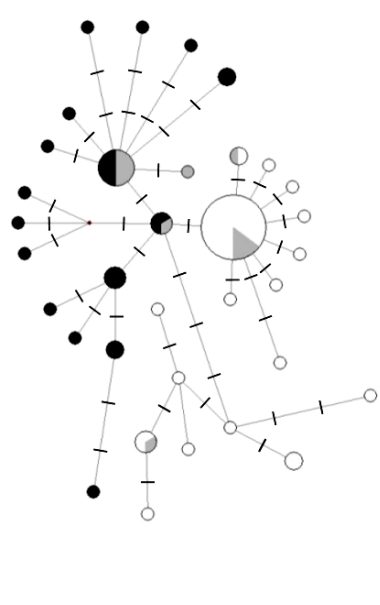

Although the disappearance of Gray-cheeked Thrushes throughout much of Newfoundland has been dramatic, little is known about the underlying causes. Changes in breeding habitat associated with forest succession or forest harvesting could have caused local declines. However, much of the habitat used by thrushes is either unaffected by forest harvesting (e.g., conifer scrub) or is created by it (regenerating clearcuts; Whitaker et al. 2015), and declines also occurred in Gros Morne National Park, a large protected area lacking industrial forestry (Lamberton 1976, Jacques Whitford Environment 1993, Rae 2014). In contrast, ecosystems on Newfoundland have been altered by the introduction of numerous species (e.g., Dodds 1983, Gosse et al. 2011, Rae et al. 2014, Strong and Leroux 2014). In particular the introduction of red squirrels (Tamiasciurus hudsonicus) in the 1960s and their rapid spread across Newfoundland in the 1970s and 1980s coincided with the period when Gray-cheeked Thrush numbers collapsed (Payne 1976, Goudie 1978, Whitaker 2015). Red squirrels have been reported to cause nesting failure in Bicknell's Thrushes (Wallace 1939, McFarland et al. 2008) and are now the dominant predator of songbird nests on Newfoundland (Lewis 2004), and recent field observations led to the hypothesis that squirrels have played a role in the decline of Gray-cheeked Thrushes (Whitaker et al. 2015).

Given the decline of the Gray-cheeked Thrushes on the island of Newfoundland, understanding the taxonomic status and current distribution of this population could play a key role in protection, conservation, and recovery planning. Our goals were (1) to clarify the taxonomic status of the Newfoundland Gray-cheeked Thrush using a population genetics approach and morphological analysis; (2) to evaluate the current distribution of thrushes on Newfoundland and in southern, central, and western Labrador, with specific attention to historically occupied regions of Newfoundland; and (3) to determine if the persistence of local breeding populations of Newfoundland Gray-cheeked Thrushes was correlated with habitat factors or with the occurrence of red squirrels.

\section{METHODS}

We carried out pilot sampling at two sites in western Newfoundland and one site in southern Labrador from 16-23 June 2013. From 5 June through 11 July of 2014 and 2015 we conducted field investigations across Newfoundland and the southern half of Labrador. Sampling spanned the reported distribution of C.m. minimus on Newfoundland and the southeast coast of Labrador, the suspected geographic range gap in southeastern and central Labrador, and areas reported to be occupied by $C$. $m$. aliciae in central and western Labrador.

\section{Genetic and morphological data collection and analyses}

We captured 51 breeding Gray-cheeked Thrushes in Newfoundland and Labrador using targeted mist netting coupled with broadcasts of thrush calls and song to attract territorial birds (Fig. 1, Appendix 1). Each captured bird was marked with a 
uniquely numbered federal leg band and then measured (relaxed [unflattened] wing chord, tail, exposed culmen), weighed, photographed, and sampled for $\sim 25-50 \mu \mathrm{L}$ of blood drawn from the brachial vein. Blood samples were immediately preserved in tubes filled with cell lysis buffer $(0.1 \mathrm{M}$ Tris- $\mathrm{HCl}, 0.1 \mathrm{M}$ EDTA, $0.01 \mathrm{M} \mathrm{NaCl}, 3 \% \mathrm{SDS})$. We obtained additional blood and tissue samples from various sources (Appendix 1) for Gray-cheeked Thrushes from Newfoundland and Labrador $(n=12)$, Harbour Island, Nova Scotia $(\mathrm{n}=2)$, as well as for individuals breeding west of Labrador $(n=13)$. We also obtained DNA data from 30 Bicknell's Thrush individuals sampled throughout their breeding range to assess the divergence between Gray-cheeked Thrush subspecies relative to the divergence between closely related species. All blood samples from our field work and the additional blood and tissue samples are archived at $-80^{\circ} \mathrm{C}$ at the New York State Museum (NYSM; Albany, NY).

DNA was extracted from blood samples using Qiagen DNEasy blood and tissue kits following the manufacturer's protocol (Qiagen, Valencia, California). We amplified and sequenced the entire 1041 base pairs (bp) mitochondrial NADH dehydrogenase 2 (ND2) gene from all individuals and two nuclear loci from subsets of individuals: a 518 bp region of the Z-chromosome gene ADAM-TS 6 from 44 Gray-cheeked and 30 Bicknell's Thrushes, and a $851 \mathrm{bp}$ region of the autosomal beta-fibrinogen intron 7 (FIB7) from 37 Gray-cheeked and 22 Bicknell's Thrushes (Appendix 1). These genetic markers have distinct inheritance modes (ND2 is maternally inherited and haploid, FIB7 is biparentally inherited and diploid in both sexes, and ADAM-TS 6 is biparentally inherited but haploid in females and diploid in males) and have been shown to provide detailed, independent assessments of divergence at the population and species level (Winker and Pruett 2006, Jacobsen et al. 2010, Hung et al. 2013). ND2 was amplified and sequenced using primers from Sorenson et al. (1999) and modified internal primers L5758 (5'GGGTGAATAGGACTGAACCAAAC-3') and H5776 (5'GAGATGGATGAGAAAGCTA-3'). ADAM-TS 6 was amplified and sequenced using PCR primers from Backström et al. (2006). FIB7 was amplified and sequenced with the primers FIBCathL1 (Winker and Pruett 2006) and FIB-B17U (Prychitko and Moore 2003). PCR products were purified using a $20-70 \%$ solution of ExoSAP-IT (Qiagen), and both strands were sequenced using Applied Biosystems Sanger sequencing chemistry and instrumentation at the Center for Functional Genomics (University at Albany, Rensselaer, NY). DNA sequences were aligned using Sequencher v. 5.4.1 (Gene Codes Corporation, Ann Arbor, Michigan), and all polymorphisms were visually confirmed from the chromatograms. To determine that our ND2 sequences were true mitochondrial genes and not nuclear copies we verified the amino acid translations and confirmed that alleles did not segregate by tissue type.

We found very low levels of polymorphism at both nuclear loci in our sample of Gray-cheeked Thrushes (see Results) that precluded informative analyses of genetic structure in this species. For our mitochondrial data we used Network v. 4.6 (http://www. fluxus-engineering.com/) to estimate a minimum spanning network of Gray-cheeked Thrush haplotypes (Bandelt et al. 1999). Uncorrected nucleotide divergence was calculated using DNASP v. 5.10 (Rozas et al. 2003). Pairwise population differentiation $\left(\varphi_{\mathrm{st}}\right)$ based on haplotype frequencies within and among regional groupings was calculated with Arlequin v. 3.5 (Excoffier et al. 2005) using the Kimura 2P mutation model with statistical significance determined by 1000 permutations of the haplotype matrix; other mutation models tested revealed similar pairwise differentiation. We defined a regional grouping as at least five geographically proximate individuals separated from other such groups of individuals by natural biogeographic barriers, e.g. mountain ranges, large bodies of water, or unsuitable habitat. This resulted in four regional groups on the island of Newfoundland (Burgeo, Avalon, Long Range Mountains, and Northern Peninsula), one group located in Southern Labrador, and one group that, because of small sample sizes, combined individuals from western Labrador with those from northern Quebec (Fig. 1). We used hierarchical analysis of molecular variance (AMOVA) to assess whether a significant proportion of genetic variation could be attributed to species or subspecies divisions, based on 20,000 permutations of the data set. To test whether subspecies correspond to monophyletic mtDNA lineages, and to estimate coalescent times for the subspecies and for our entire sample of Gray-cheeked Thrush, we used BEAST v.2.1.3 (Drummond et al. 2012, Drummond and Bourckaert 2015) with a Hermit Thrush sequence (C. guttatus; NYSM zt-1223) as an outgroup. The HKY model was determined to be the best model of nucleotide substitution using PartitionFinder v1.1.0 (Lanfear et al. 2012) according to Bayesian information criterion (BIC). Bayesian maximum clade credibility trees were created using a relaxed lognormal clock, a substitution rate of 0.0145 substitutions/site/ lineage/million years (Lerner et al. 2011) and the coalescent exponential population model. We tested models where monophyly was constrained for each subspecies and in which monophyly was unconstrained. We first ran a model for 10,000,000 generations using all default priors and sampling every 2000 trees, and then used the estimated means for gamma and kappa parameters in three subsequent runs of 50,000,000 generations, sampling every 10,000 trees. All files were formatted using BEAUti 2 (Drummond et al. 2012). Convergence was assessed with Tracer v.1.6.0 (Rambaut et al. 2014) and the maximum clade credibility tree was determined with TreeAnnotator v.2.1.2 (http://beast.bio. ed.ac.uk/treeannotator) using a $25 \%$ burn-in. Node support and age estimates were examined using FigTree v.1.4.0 (http://tree.bio. ed.ac.uk/software/figtree/).

We augmented our data on wing chord, tail length, exposed culmen, and mass with measurements of breeding birds captured during previous and subsequent work by us in western Newfoundland (I. G. Warkentin and D. M. Whitaker, unpublished data), as well as two birds banded by staff from Bird Studies Canada on Harbour Island, Nova Scotia, four birds banded by W. G. Ellison from the Northern Peninsula of Newfoundland and western Labrador, four specimens from southern Labrador and Saint Pierre and Miquelon measured by J. T. Marshall (2001), and eight birds banded in northern Quebec by the Canadian Wildlife Service (Y. Aubry, unpublished data). Rigorous comparison of subtle variation in plumage or bare parts coloration is not easily achieved in the field or from photographs taken under varying light conditions, so we devised a more objective method to assess variation in extent of pale color at the base of the lower mandible from photographs taken during banding. For each high-quality photograph, three of us independently measured the proportion of black along the distal portion of the lower mandible, i.e., the 
ratio of the length of the black tip to the total length of the mandible, which represents the inverse of the extent of pale color at the base of the mandible. Assessors were blind to both the geographic origin of each bird and the measurements of the others, and we took the average of the three measurements as the estimate for each thrush.

We compared morphological traits of Gray-cheeked Thrushes between three regions: all of Newfoundland (including two thrushes from Harbour Island, Nova Scotia); southern Labrador; and a combination of samples from western Labrador and Quebec. We used Analysis of variance (ANOVA) to assess whether each morphological trait varied across these three regions, and then used Tukey's Honestly Significant Difference method to test for differences between pairs of regions in $R$ ( $R$ Core Development Team 2015). Because morphology may vary between sexes we analyzed males and females separately; however there were too few females to allow for rigorous comparisons so we only present results for males.

\section{Distribution and habitat surveys and analyses}

To document the distribution and abundance of Gray-cheeked Thrushes, we conducted standardized surveys at sites with known extant populations and sites of documented historical occupancy. Survey sites encompassed the full suite of breeding habitat types reported in the literature, including low and high elevation conifer scrub, willow and alder thickets, regenerating clearcuts and montane old-growth fir forest. Special efforts were made to visit sites known to have supported high densities of Gray-cheeked Thrushes in the past, which were identified through reviews of (1) BBS 10-stop summaries from 1966-1996 and BBS 50-stop summaries from 1997-2014; (2) museum specimen occurrences in the VertNet (http://vertnet.org/) and Canadian Museum of Nature (http://collections.nature.ca/en/Search) databases; (3) avian observation databases such as eBird (http://ebird.org/ content/ebird/) and the Global Biodiversity Information Facility (http://www.gbif.org/); (4) the bird watching newsgroup nf.birds (https://groups.google.com/forum/\#!forum/nf.birds); (5) published records by Lamberton (1976) and Marshall (2001); and (6) the Government of Newfoundland Species Status Advisory Committee report for Gray-cheeked Thrush (SSAC 2010).

At each site we surveyed 3-10 points for 10 minutes each between 04:25 $\mathrm{h}$ and 10:00 h. Surveys began with 10 minutes of silent listening, during which time we recorded all birds detected. If no Gray-cheeked Thrushes were detected, this 10-minute period was followed by a 2-minute broadcast of the species' calls and song (Betts et al. 2005, Whitaker et al. 2015) and then an additional 2minute silent listening period. Adjacent survey points were separated by at least $250 \mathrm{~m}$, which exceeded the human limit for detection of the song and call broadcast and typically leads to independence of bird observations (Whitaker et al. 2015). When historical records of Gray-cheeked Thrushes contained locality information with large geographic uncertainties, we conducted extensive area searches. Area searches were performed by walking along a road or trail while periodically broadcasting a 2 -minute recording of Gray-cheeked Thrush vocalizations followed by periods of silent listening. All bird observations from our point count surveys and area searches have been entered into the eBird bird observation database.
To quantify habitat at survey points we measured 19 attributes of vegetation composition and structure in $4 \mathrm{~m} \times 20 \mathrm{~m}$ transects $(80$ $\mathrm{m}^{2}$ sampling area; hereafter, local habitat variables). Canopy height was estimated using a clinometer. Ground cover composition (quantified within eight $0.25 \mathrm{~m}^{2}$ quadrats placed within the sampling area) included the percentage of litter, woody debris, moss and lichen, and herbaceous understory. Vertical density was quantified as the proportion of space from $0-2 \mathrm{~m}$ above a quadrat occupied by vegetative material. Canopy cover was estimated with a densitometer. Within each transect, we tallied the abundance of every tree species, and placed all trees into size classes based on diameter at breast height (DBH). In our final analysis we split all tree groups into two DBH size classes, < $8 \mathrm{~cm}$ or $>8 \mathrm{~cm}$, and included the abundance of balsam fir, black spruce (Picea mariana), white spruce ( $P$. glauca), tamarack (Larix laricina), broadleaf trees (all species combined), and standing dead snags (all species combined). We also estimated the extent of four coarse vegetation types within a $1250-\mathrm{m}$ radius of each survey point (hereafter, landscape habitat variables; Leonard et al. 2008) using the Earth Observation for Sustainable Development of Forests (EOSD) satellite data (25-m resolution; Wulder and Nelson 2003). These variables were (1) conifers (combined proportion of EOSD rasters within $1250 \mathrm{~m}$ classified as Coniferous, Coniferous-dense, Coniferous-open, or Coniferoussparse); (2) dense conifers (proportion of rasters classified as Coniferous-dense); (3) shrubs (combined proportion of rasters classified as Shrubland, Shrubs-tall, or Shrubs-short); and (4) mixed deciduous and coniferous forests (combined proportion of rasters classified as Mixedwoods, Mixedwoods-dense, Mixedwoodsopen, or Mixedwoods-sparse).

We analyzed habitat data in two ways. First, we used a single-visit occupancy model (Lele et al. 2012) implemented in R package detect (Sólymos et al. 2016) to test for the effects of each of our local and landscape habitat variables on occupancy, while accounting for detection probability. Date (day of year), number of trees in local habitat surveys, and percentage of conifers in local habitats were initially used as covariates of detection. However, all models were improved by removing percentage of conifers, so all models reported below used only day of year and number of trees as covariates of detection. A full occupancy model including all habitat variables did not converge, so we analyzed 23 separate univariate models, and ranked models according to AIC. We then used a forward stepwise approach, starting with the univariate model having the lowest AIC, adding variables that improved model performance (lower AIC) until the model became too complex to converge.

Second, we tested whether habitat characteristics differed between sites where Gray-cheeked Thrushes were present (combined across point counts for that site) and those where they have disappeared. To do this, we first categorized our sites as currently occupied (detected during our area searches, point counts, and mist netting efforts from 2014-2015), historically occupied (sites with documented records of occurrence but no detections during our surveys), or absent (no historic records and no detections during our surveys). Sites were categorized as historically occupied if they were $<10 \mathrm{~km}$ from a historical observation; only three of these historical records may have been $>5 \mathrm{~km}$ from our survey sites. We compared each habitat variable present in the top occupancy model between current and historically occupied sites. We used a Welch's two-sample $t$ test for this comparison when the 
data were normal according to a Shapiro-Wilk test, or a MannWhitney U test when they were not.

Finally, during the course of this study a new hypothesis emerged that suggested that the introduction of red squirrels played a role in the decline of Gray-cheeked Thrushes on Newfoundland (Whitaker et al. 2015). Much like songbirds, red squirrels use vocalizations as alarm calls and for territorial defence and are often visible to observers; they also leave physical evidence of their presence in the form of deposits of cone scales and middens. Consequently, during the 2015 field season we also recorded whether squirrels or physical evidence of squirrels were detected at survey points during bird surveys or vegetation sampling. We then used a Chi-squared test to evaluate the association between detections of thrushes and squirrels. Similarly, we calculated the odds ratio to estimate the relative likelihood of detecting thrushes at points where squirrels were or were not detected.

\section{RESULTS}

\section{Genetic and morphological variation}

In our sample of 44 Gray-cheeked and 30 Bicknell's Thrushes sequenced for the Z-chromosome gene ADAM-TS 6 (518 bp), 69 individuals were homozygous and identical at all nucleotides, and only 5 were heterozygous at a single polymorphic nucleotide. The five heterozygous male Gray-cheeked Thrushes were sampled from Alaska, southern Labrador, and three locations on Newfoundland (Patrick's Cove, Main River watershed, and La Manche). Among 37 Gray-cheeked Thrushes and 22 Bicknell's Thrushes sequenced for FIB7 (851 bp), only 2 of 9 polymorphic sites were shared by multiple individuals. At the first of these two variable sites 10 Bicknell's Thrushes and one Gray-cheeked Thrush from southern Labrador (NYSM zt-1278) were heterozygous with the same two alleles. At the second site all Graycheeked Thrushes except NYSM zt-1278 were homozygous with a ' $C$ ' allele, and 17 of 22 Bicknell's Thrushes were homozygous with a 'T' allele. Five Bicknell's Thrushes and NYSM zt-1278 were heterozygous ( $\mathrm{C}$ and $\mathrm{T})$ at this site. Thus, there was essentially no divergence at ADAM-TS 6 and a single polymorphic site at FIB7 between Gray-cheeked and Bicknell's Thrushes, and these loci were not informative with respect to regional or subspecific groupings of Gray-cheeked Thrushes.

Our analyses of complete ND2 sequences (1041 bp) from all 78 Gray-cheeked Thrushes and 29 Bicknell's Thrushes showed that the pairwise, uncorrected genetic distance between the two species averaged $2.33 \%$ nucleotide divergence (range 2.02-2.69\%). The Gray-cheeked Thrush from southern Labrador that was heterozygous at FIB7 (NYSM zt-1278) carried a haplotype that is widespread and common in our sample of Bicknell's Thrushes, but not found in any other Gray-cheeked Thrush. This suggests that this individual, phenotypically a Gray-cheeked Thrush based on wing chord $(101 \mathrm{~mm})$, tail length $(72 \mathrm{~mm})$, and mass $(34 \mathrm{~g})$, and caught well within the Gray-cheeked Thrush range, is of mixed origin. This finding could not have been the result of an error in the field because no Bicknell's Thrushes were sampled in 2015. We ruled out the possibility of an error in the laboratory by conducting a second DNA extraction from a new aliquot of the blood sample in the NYSM ancient-DNA laboratory, where no previous DNA work has been performed on any thrush species, and then amplifying and resequencing. Because of its hybrid origin, this individual was removed from subsequent analyses of genetic structure among Gray-cheeked Thrushes.

We found high levels of ND2 sequence polymorphism within our samples of both Gray-cheeked and Bicknell's Thrushes. Pairwise distances within species averaged $0.30 \%$ (range $0.00-0.96 \%$ ) for Gray-cheeked-Thrush and $0.15 \%$ (range $0.00-0.38 \%$ ) for Bicknell's Thrush. Pairwise distances between the Northern Graycheeked Thrush (C. m. aliciae) and Newfoundland Gray-cheeked Thrush (C. m. minimus) subspecies also averaged $0.30 \%$. The AMOVA with Bicknell's Thrushes, Northern Gray-cheeked Thrushes, and Newfoundland Gray-cheeked Thrushes designated as groups showed that $84 \%$ of the genetic variance was partitioned among these groups $(p<0.05)$. There were no genetic breaks across the putative subspecies boundary in Labrador, or across the Strait of Belle Isle that separates Newfoundland from Labrador (Fig. 1). However, our haplotype network revealed a detectable geographic pattern of genetic structure in the clustering of haplotypes sampled on Newfoundland, which were separated by short genetic distances from all birds sampled in western Labrador and points farther west in the species' range (Figure 1B). The 12 thrushes sampled from southeastern Labrador had an equal mix of the haplotypes found in the two putative subspecies. Two Gray-cheeked Thrushes captured on Harbour Island, Nova Scotia, in 2010 were genetically most similar to Newfoundland Gray-cheeked Thrushes and are hereafter considered part of C. m. minimus in analyses based on subspecies groupings.

Pairwise comparisons of genetic variation among regional groupings (Table 1) using $\varphi_{\text {st }}$ values indicated that Northern Graycheeked Thrushes from western Labrador/Quebec and Alaska ( $C$. $m$. aliciae) were highly differentiated from all regional groupings on the island of Newfoundland $\left(\varphi_{\mathrm{st}}\right.$ range: $\left.0.314-0.601, p<0.05\right)$. The southern Labrador group showed low to moderate levels of differentiation from all Newfoundland regional groups $\left(\varphi_{\mathrm{st}}\right.$ range: $0.129-0.227 ; p<0.05)$ and western Labrador/Quebec $\left(\varphi_{\mathrm{st}} 0.111\right.$; $p<0.05)$ but showed strong differentiation when compared with Alaska $\left(\varphi_{\text {st }} 0.111 ; p<0.05\right)$. Samples from Burgeo were not significantly different from any other Newfoundland group $(p>$ $0.05)$; in contrast, the Long Range Mountain group showed low to moderate differentiation with all other $C$. $m$. minimus groupings, except for Burgeo ( $\varphi_{\text {st }}$ range: $0.227-0.334 ; p<0.05$ ). Although 15 of 17 birds from the Avalon region had identical ND2 sequences, the Avalon group was not significantly different from Burgeo or the Northern Peninsula $(p>0.05)$ but showed low to moderate differentiation from the Long Range Mountains $\left(\varphi_{\text {st }} 0.286 ; p<0.05\right)$ and southern Labrador $\left(\varphi_{\text {st }} 0.145 ; p<0.05\right)$, and strong differentiation from $C$. m. aliciae groupings $\left(\varphi_{\mathrm{st}}\right.$ range: $0.446-0.562 ; p<0.05)$.

AMOVAs within Gray-cheeked Thrushes were used to test three comparisons: (1) C. m. aliciae vs. C. m. minimus, the latter including southeastern Labrador birds $(d f=5)$; (2) individuals from Newfoundland vs. all other regional groupings of all Graycheeked Thrushes, the latter including birds from southeastern Labrador ( $d f=5$ ); and (3) individuals from Newfoundland vs. $C$. $m$. aliciae, both excluding southern Labrador $(d f=4)$. Comparisons (1) and (2) showed that most of the variation $(62 \%$ and $64 \%$, respectively) was partitioned within regional groups, with much less variation ( $17 \%$ and $15 \%$, respectively) explained 
Table 1. Pairwise $\varphi$ st based on mitochondrial ND2 between all regional groupings of Gray-cheeked Thrushes (Catharus minimus). The number of samples in each group is indicated in parentheses. Significance was determined from 1000 permutations in Arlequin using the Kimura 2P mutation model. Refer to Appendix 1 and Figure 1 for the geographical location of each group and other sampling details. Note that the western Labrador / Quebec (i.e. W. Lab/QC) and Alaska groupings fall within the range of the putative $C$. $m$. aliciae subspecies while all other samples fall within the range of the putative C. m. minimus subspecies.

\begin{tabular}{|c|c|c|c|c|c|c|c|}
\hline & Burgeo & Avalon & $\begin{array}{c}\text { Long Range } \\
\text { Mts. }\end{array}$ & N. Peninsula & S. Labrador & W. Lab/QC & Alaska \\
\hline Burgeo (5) & & & & & & & \\
\hline Avalon (17) & 0.141 & & & & & & \\
\hline Long Range Mts. (10) & 0.019 & $0.286^{*}$ & . & & & & \\
\hline N. Peninsula (7) & 0.219 & 0.017 & $0.334^{*}$ & & & & \\
\hline S. Labrador (12) & $0.129^{*}$ & $0.145^{*}$ & $0.227^{*}$ & $0.183^{*}$ & & & \\
\hline W. Lab/QC (14) & $0.355^{*}$ & $0.446^{*}$ & $0.401 *$ & $0.463^{*}$ & $0.111^{*}$ & & \\
\hline Alaska (7) & $0.314 *$ & $0.562^{*}$ & $0.434 *$ & $0.601 *$ & $0.412 *$ & $0.443 *$ & \\
\hline
\end{tabular}

by broader groupings corresponding to the putative subspecies. Removing the southeastern Labrador birds (comparison 3) resulted in $57 \%$ of the variance being explained within regional groups and $20 \%$ of the variance partitioned among the broad groupings of Newfoundland and $C$. m. aliciae. All AMOVA calculations were significant $(p<0.05)$.

Node support values and coalescent time estimates for subspecies and for all Gray-cheeked Thrushes were highly congruent among the three randomly-seeded BEAST runs. When subspecies monophyly was unconstrained we found that subspecies were not reciprocally monophyletic; nodes within Gray-cheeked Thrush generally had posterior probabilities $<0.65$. The median age of the node uniting all Gray-cheeked Thrushes ranged from 235$238 \mathrm{ky}$ in both constrained and unconstrained runs $(95 \% \mathrm{CI}=$ $10-1280 \mathrm{ky})$. In the monophyly-constrained runs, the median age of the $C$. m. minimus node was $129-132 \mathrm{ky}(95 \% \mathrm{CI}=5.3-649$ ky), and the median age of C. m. aliciae was $111-114 \mathrm{ky} \mathrm{(95 \%} \mathrm{CI}$ $=4.4-518 \mathrm{ky})$.

Analysis of morphological data indicated that male Gray-cheeked Thrushes from Newfoundland, i.e., C. m. minimus, had shorter wings, tails, and exposed culmens and had less extensive black in the tip of the lower mandible than those from western Labrador and Quebec, i.e., C. m. aliciae (Table 2). Thrushes from southern Labrador also had shorter wings than those from western Labrador and Quebec, but were intermediate in tail length and extent of black in the mandible and had longer exposed culmens than those from Newfoundland (Table 2). Thrush mass did not vary across regional groupings. Note that a male thrush from Quebec had a reported wing chord of $92 \mathrm{~mm}$ but was typical in terms of tail length $(72 \mathrm{~mm})$ and exposed culmen $(12.5 \mathrm{~mm})$. As this wing length was well outside the range observed for any region (see also Ouellet 1993) it was considered an outlier and dropped from that analysis. However had it been retained the mean wing chord of males from Newfoundland would still have been significantly shorter than that of males from western Labrador and Quebec.

\section{Distribution and habitat}

We conducted a total of 167 point counts for Gray-cheeked Thrushes at 29 sites in 10 regional grouping areas across Newfoundland and southern, central, and western Labrador (Fig. 2, Appendix 1). We observed 53 individual thrushes at 13 of the sites sampled, and 13 of these thrushes were not detected until the broadcast portion of the survey. Additional area searches covered $>300 \mathrm{~km}$, and thrushes were detected during 10 of 40 searches. We failed to detect Gray-cheeked Thrushes in areas where they historically were found in or near Terra Nova National Park in eastern Newfoundland, near Grand Falls-Windsor in central Newfoundland, and at several sites in southwestern Newfoundland. We also did not find Gray-cheeked Thrushes in the reported historical distributional gap from Mary's Harbour north to Cartwright in Labrador.

Fig. 2. Gray-cheeked Thrush (Catharus minimus) surveys completed in Newfoundland and Labrador, 2014-2015. Circles show sites of point counts and vegetation surveys; crosses indicate additional areas that were searched but where no point counts were conducted and where no thrushes were found. Historically present sites are those where thrushes were found in the past but were not observed during our surveys. The dotted lines represent the putative range gap between the subspecies. Some occurrence points have been offset to better show clustered survey sites.

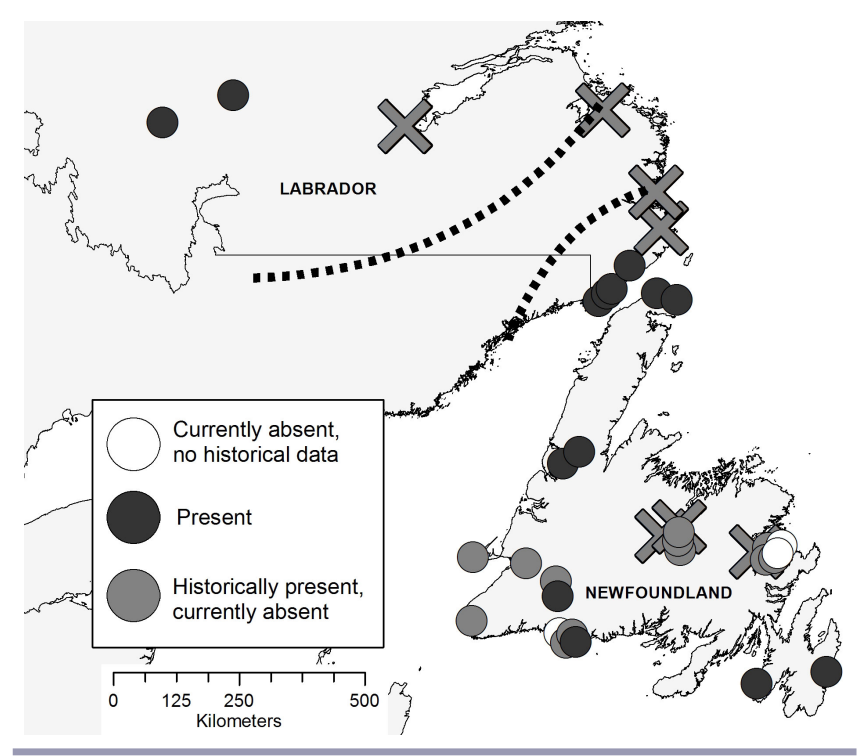


Table 2. Morphological traits of male Gray-cheeked Thrushes (Catharus minimus) captured during the breeding season. Analysis of variance was used to test whether each trait differed across regions, while Tukey's Honestly Significant Difference method was used to compare pairs of regions.

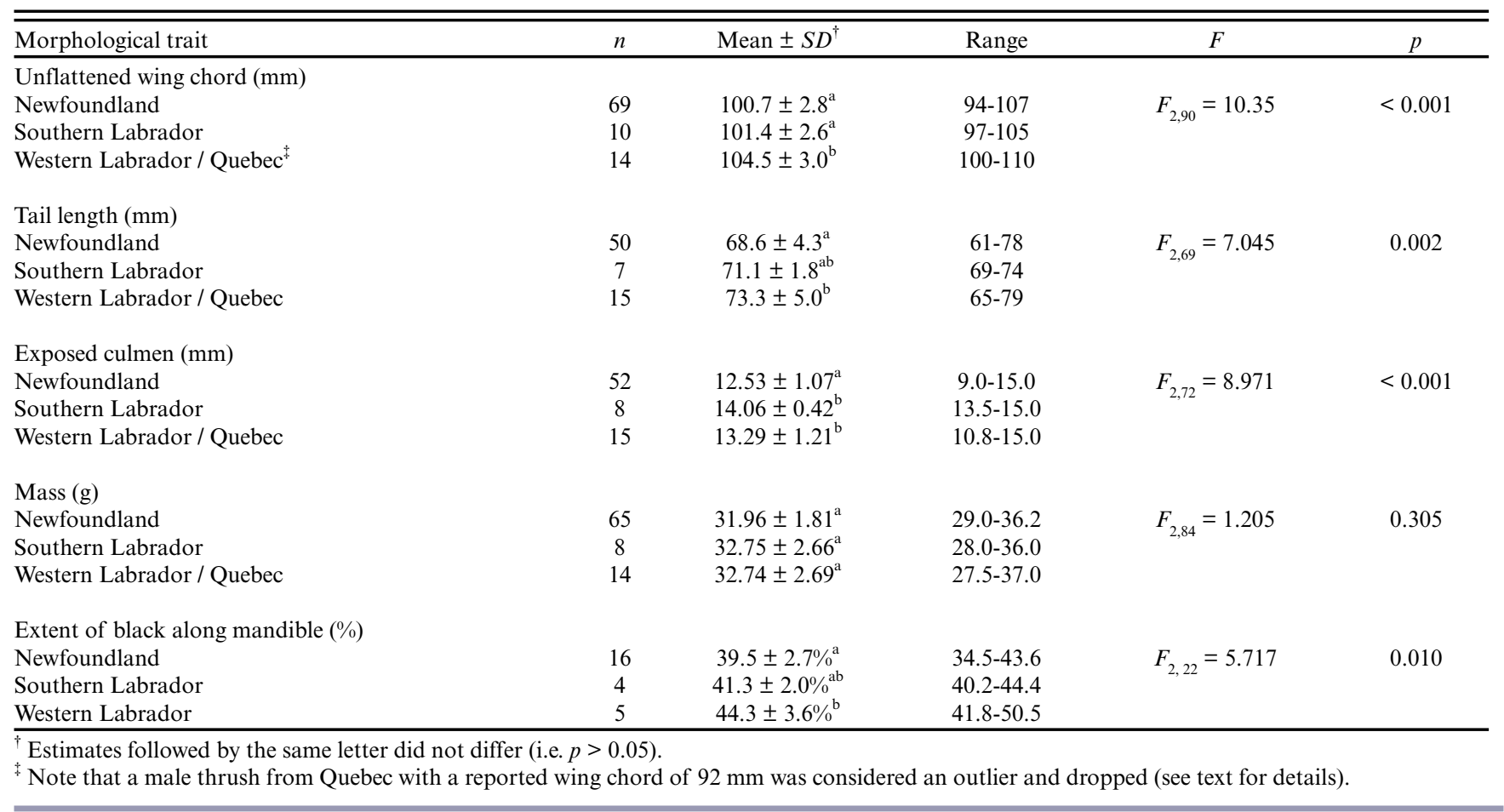

Of the 23 univariate occupancy models, landscape coverage of shrub habitat had the lowest AIC, and was the only model with a significant slope (AIC $=33.86, p=0.0216$ ). Adding local abundance of large broadleaf trees had the largest effect on reducing model AIC $($ AIC $=31.42$, delta AIC $=-2.43$. Adding a third variable resulted in nonconvergence of the model. Therefore, the best model indicated that Gray-cheeked Thrush occupancy in Newfoundland and Labrador is positively associated with landscape cover of shrub habitats (slope $=1.7147$, $p=0.0182$ ), and negatively associated with local abundance of large broadleaf trees (slope $=-2.7163, p=0.0933$ ). Also, both landscape coverage of shrub habitat and local abundance of large broadleaf trees differed significantly between currently and historically occupied sites. Sites where Gray-cheeked Thrushes have apparently disappeared had less shrub cover in the surrounding landscape $(t=-3.29, d f=15.6, p=0.005)$ and higher local abundance of large broadleaf trees $(U=46, p=0.042)$.

A Chi-squared test comparing Gray-cheeked Thrush detections based on whether or not red squirrels were observed revealed that we were more likely to observe thrushes at sites where we did not observe squirrels ( $n=113$ points; $\left.\chi^{2}=4.61, d f=1, p=0.032\right)$. We calculated the odds ratio as 3.31 (95\% CI: $1.20-9.15)$, indicating that thrushes were in excess of three times more likely to be detected at points where squirrels were not observed. We attempted to add squirrels as an explanatory variable to our best occupancy model to see if it would improve performance, but the model did not converge. After simplifying the model by removing number of trees as a covariate of detection (keeping only day of year) and broadleaf trees as covariate of occupancy the model did converge; however this model with percent shrubs in the landscape and occurrence of red squirrels showed no improvement in explanatory power $(\mathrm{AIC}=24.59)$ compared to a model with only percent shrubs (AIC $=22.66$, delta AIC $=1.93)$. Note that these models were fit using data from the subset of sites surveyed for squirrels in 2015.

\section{DISCUSSION}

Though nuclear intron data were not informative regarding genetic structure within the Gray-cheeked Thrush, we found evidence from mitochondrial DNA (ND2) and morphology that supports the current taxonomic splitting of the species into two subspecies: C. m. minimus in Newfoundland and southeastern Labrador and C. m. aliciae from central Labrador west to Siberia. Data from autosomes and sex chromosomes do not contradict our results from the mitochondrial genome. They indicate that differences between subspecies, as expected, are slight, and that the divergence between Gray-cheeked and Bicknell's Thrushes are recent. The greater divergence of mitochondrial genes we observed is expected given the smaller effective population size and faster coalescence of the mitochondrial genome (Zink and Barrowclough 2008). We observed shallow mitochondrial divergence between birds on Newfoundland and those from regions further west, but also an absence of shared haplotypes. Further, as has been reported previously, we found that Graycheeked Thrushes on Newfoundland had shorter wings and had less black in the lower mandible than those from the range of $C$. m. aliciae (Table 2; Ouellet 1993, Marshall 2001). We also found that Newfoundland thrushes had shorter tails and exposed 
culmens, though note that Ouellet (1993) found that these traits did not differ between Quebec and Newfoundland. Thrushes captured on the north shore of the Strait of Belle Isle in southeastern Labrador resemble those from Newfoundland in terms of wing length, but were intermediate in terms of tail length and extent of black in the mandible and had longer exposed culmens than thrushes from Newfoundland. They also had an equal mix of the mitochondrial haplotypes found in C. m. aliciae to the north and west, and C. m. minimus to the southeast (Fig. 1). Pairwise $\varphi_{\text {st }}$ comparisons also support the conclusion that thrushes in southeastern Labrador are a link between two regions that are otherwise distinct. Our coalescent analyses showing that subspecies are not reciprocally monophyletic suggest that there is gene flow or retained ancestral polymorphism, as is expected between subspecies that are not considered to be reproductively isolated. Our extensive surveys between the southeastern coast of Labrador and central Labrador ( $>143 \mathrm{~km}$ of roads and trails covered) suggest that the previously reported distributional gap between subspecies may be real (Fig. 2; see also Todd 1963, SSAC 2010, Lewis and Starzomski 2015, Quebec Breeding Bird Atlas 2016). As a result, we suspect that the level of gene flow is greater across the 15-60 km wide Strait of Belle Isle than across the 150 $350 \mathrm{~km}$ wide apparent distributional gap between southeastern Labrador and central Labrador (see Fig. 1).

Based on shallow divergence of mitochondrial cytochrome $b$ sequences and a lack of shared haplotypes from distal parts of the Gray-cheeked Thrush breeding range in North America (i.e., Newfoundland, $n=5$ and Alaska, $n=10$ ), Topp et al. (2013) suggested that birds from these two regions may have experienced a vicariant split in the Late Pleistocene. Our findings agree with Topp et al. (2013) and yield finer scale details regarding the phylogeography of this species. Because our work draws on a larger number of samples collected in more locations, we have been able to identify the distribution gap between the north side of the Strait of Belle Isle and central Labrador, rather than a break at some point further west, e.g., Hudson Bay or the Rocky Mountains, as the geographic boundary between the two weakly differentiated subspecies. The genetic distinctiveness of the Newfoundland population of Gray-cheeked Thrush mirrors that found in other bird species (e.g., Holder et al. 2004, Ralston and Kirchman 2012, Lait and Burg 2013), and is consistent with the hypothesis that a Pleistocene refugium for boreal species existed off of the coast of Newfoundland. Our estimates of the age of the split of the Gray-cheeked Thrush mitochondrial lineages (235-238 kya) correspond to a period of receding glaciation and rising oceans (Shackleton and Opdyke 1976), when boreal habitats were beginning to expand northward from isolated refugia. Gray-cheeked Thrushes residing in the hypothesized Atlantic Shelf refugium may have diverged in allopatry from birds residing in one or more western refugia. However we caution that our divergence-time estimates and those of Topp et al. (2013) have large confidence intervals and are based on a single genetic marker.

The Burgeo population was not significantly different from any other Newfoundland group, although this may be an artefact of small sample size (Table 1). Despite a large sample size, however, birds from the Avalon Peninsula were not significantly different from the Burgeo or Northern Peninsula groupings, and showed low differentiation from southern Labrador; this lack of significant differentiation may be due to the fact that 15 of 17 individuals from the Avalon group had identical ND2 sequences despite being sampled from four sites (Appendix 1). Conversely, birds from the highlands of the Long Range Mountains of western Newfoundland showed low to moderate differentiation from other C. m. minimus groupings (excluding Burgeo) and were particularly diverse, with 10 birds carrying a total of 7 haplotypes. This is possibly an indication that the large, contiguous montane forest in this part of Newfoundland has a correspondingly large and diverse gene pool. This interpretation is consistent with other research showing that there is a large residual population of Graycheeked Thrushes at elevations above $375 \mathrm{~m}$ in the Long Range Mountains (Whitaker et al. 2015).

We also found that the degree of genetic divergence within Graycheeked Thrushes was similar to that found in Bicknell's Thrushes, and that these two species are divergent from one another at a deeper level, with the important exception of one putative hybrid individual that we captured in southern Labrador. This bird was phenotypically a Gray-cheeked Thrush, but possessed a Bicknell's Thrush mitochondrial haplotype. At the nuclear FIB7 intron, the putative hybrid possessed a T allele that had a frequency of 0.014 in Gray-cheeked Thrush (including the putative hybrid) and 0.886 in Bicknell's Thrush, suggesting that the heterozygosity at this site may be due to hybridization rather than retained ancestral polymorphism. The mitochondrial haplotype of the putative hybrid from southern Labrador, the allele frequency distributions of FIB7, and the fact that all heterozygous Bicknell's Thrushes were sampled in the northern reaches of that species' range suggest that occasional hybridization may occur where their ranges abut along the north shore of the Gulf of St. Lawrence or on islands around Nova Scotia and in the gulf, as suggested by Marshall (2001). The geographic boundaries of the breeding ranges of these two species are not clearly established and they may have been separated by less than $60 \mathrm{~km}$ along the north shore of the Gulf of St. Lawrence in the past century (Marshall 2001) before the breeding range of Bicknell's Thrush became more restricted (Ouellet 1993, COSEWIC 2009). Similarly, Graycheeked Thrushes may have experienced a range contraction eastwards along the north shore of the Gulf of St. Lawrence (Marshall 2001).

On Newfoundland Gray-cheeked Thrushes have persisted in the highlands of the Long Range Mountains, along Burgeo Road, and in some coastal areas including the Avalon Peninsula and the northern tip of the Northern Peninsula. In contrast we failed to find them in some areas where they were reported in the past, including central Newfoundland (Terra Nova National Park, Grand Falls-Windsor area), the southwestern corner of the island, and the coastal town of Burgeo where the most recent reported sightings date from 2003. These findings are consistent with BBS data and surveys of Gros Morne National Park (Lamberton 1976, Jacques Whitford Environment 1993, SSAC 2010), which collectively indicate that this species has disappeared from many low elevation areas throughout Newfoundland since the early 1980 s.

Our habitat analyses indicate that in Newfoundland and Labrador Gray-cheeked Thrushes have persisted at sites that currently have a low abundance of large broadleaf trees and in landscapes having high availability of shrub cover. This may 
reflect some change in habitat suitability for thrushes because of vegetation succession, as published descriptions of Graycheeked Thrush habitat use indicate that they are associated with dense shrub thickets and regenerating and old-growth conifer forests (e.g., Lowther et al. 2001, Whitaker et al. 2015). However recent research also led to the hypothesis that the introduction of red squirrels, a novel nest predator on Newfoundland, may have contributed to the rapid decline in Gray-cheeked Thrushes (Whitaker et al. 2015). Consistent with this, we also found that thrushes were greater than three times more likely to be detected at sites where squirrels were not observed. Historically Graycheeked Thrushes were widespread and common on Newfoundland and may have used a broader range of habitat types than those on mainland North America (e.g., Marshall 2001, SSAC 2010). Thus it may be that the introduction of squirrels led to niche contraction, whereby thrushes were no longer able to persist in habitat types suitable for squirrels. Although inclusion of squirrel occurrence in our thrush occupancy models did not improve performance, ongoing research investigating habitat segregation between thrushes and squirrels on Newfoundland may shed light on this conjecture. Red squirrels are a pervasive predator of landbird nests and fledglings throughout the boreal forest (e.g., Lewis 2004, Haché et al. 2014) so we suggest that squirrel observations be recorded in boreal bird surveys. This may provide insight into the role of this predatory mammal in shaping bird communities and may be particularly important on Newfoundland, which supports a relatively high level of endemism within the boreal forest and where impacts of squirrels and other introduced species on biodiversity remain poorly studied.

In summary, our morphological and genetic data indicate that Gray-cheeked Thrushes of Newfoundland and southeastern Labrador are weakly differentiated from those found further west in the species' breeding range. Coupled with our observations supporting the existence of a substantial geographic gap between these populations, these findings suggest that the Newfoundland subspecies $C$. m. minimus is a recognizable population unit with a limited but significant independent evolutionary history. It is imperative that research and management action be taken to better understand the dramatic decline that this subspecies has experienced over the past 30-40 years and to maintain or recover the population on Newfoundland. Fruitful areas for future research include investigation of the role of introduced species on thrush distribution and productivity on Newfoundland, and assessment of migratory connectivity to elucidate the role that issues on nonbreeding grounds may be playing in the decline of the Newfoundland subspecies and possibly also mainland populations.

Responses to this article can be read online at: http://www.ace-eco.org/issues/responses.php/976

\section{Acknowledgments:}

Research was supported through funds from the Centre for Forest Science and Innovation (Newfoundland and Labrador [NL]
Department of Natural Resources), the Natural Sciences and Engineering Research Council of Canada, the New York State Museum, and Utica College. Logistical and in-kind support was provided by the NL-Wildlife Division and Gros Morne National Park. Assistance in the field was provided by Rinchen Boardman, Edward FitzGerald, Matthew Halley, Kathryn Hoo, Jenna McDermott, Randy Thompson, Robert Vlug and Eastern Outdoors, Lucy Welsh, and Celina Willis. Additional tissue samples and morphological data were provided by the American Museum of Natural History, New York State Museum, University of Alaska Museum, University of Washington Burke Museum, Canadian Wildlife Service, and Bird Studies Canada. We thank Ellen Martinsen for advice regarding lab work, Péter Sólymos for statistical advice, and the associate editor and reviewers for their constructive comments on the original manuscript. Thanks are also extended to individuals who reported thrush observations during field surveys, including Vernon Buckle, Alvan Buckley, Jared Clarke, Marie-Anne Hudson, Tina Leonard, and Peter Thomas. Research was conducted under banding and tissue collection permits from the Canadian Wildlife Service as well as scientific permits from the NLWildlife Division, NL-Parks and Natural Areas Division and Parks Canada, and animal care approval from Memorial University of Newfoundland and the State University of New York at Albany.

\section{LITERATURE CITED}

American Ornithologist's Union (AOU). 1998. Checklist of North American birds. Seventh edition. Allen Press, Lawrence, Kansas, USA.

Backström, N., M. Brandström, L. Gustafsson, A. Qvarnström, H. Cheng, and H. Ellegren. 2006. Genetic mapping in a natural population of Collared Flycatchers (Ficedula albicollis): conserved synteny but gene order rearrangements on the avian $\mathrm{Z}$ chromosome. Genetics 174: 377-386. http://dx.doi.org/10.1534/ genetics.106.058917

Bandelt, H.-J., P. Forster, and A. Röhl. 1999. Median-joining networks for inferring intraspecific phylogenies. Molecular Biology and Evolution 16:37-48. http://dx.doi.org/10.1093/ oxfordjournals.molbev.a026036

Betts M. G., A. S. Hadley, and P. J. Doran. 2005. Avian mobbing response is restricted by territory boundaries: experimental evidence from two species of forest warblers. Ethology 111:821-835. http://dx.doi.org/10.1111/j.1439-0310.2005.01109. $\mathrm{x}$

Bird Studies Canada and North American Bird Conservation Initiative (NABCI). 2014. Bird conservation regions. Bird Studies Canada, Port Rowan, Ontario, Canada. [online] URL: http:// www.birdscanada.org/research/gislab/index.jsp?targetpg=bcr

Colbeck, G. J., H. L. Gibbs, P. P. Marra, K. Hobson, and M. S. Webster. 2008. Phylogeography of a widespread North American migratory songbird (Setophaga ruticilla). Journal of Heredity 99 (5):453-463. http://dx.doi.org/10.1093/jhered/esn025

Committee on the Status of Endangered Wildlife in Canada (COSEWIC). 2009. COSEWIC status report on the Bicknell's Thrush (Catharus bicknelli) in Canada. COSEWIC, Ottawa, Ontario, Canada. [online] URL: http://www.registrelepsararegistry.gc.ca/document/default_e.cfm?documentID $=1137$ 
Dickinson, E. C., and L. Christidis, editors. 2014. The Howard and Moore complete checklist of the birds of the world. Fourth Edition, Vol 2. Aves Press, Eastbourne, UK.

Dodds, D. 1983. Terrestrial mammals. Pages 163-206 in R. South, editor. Biogeography and ecology of the island of Newfoundland. Springer, The Hague, The Netherlands.

Dohms, K. M. 2016. Phylogeography of three high latitude resident corvids: Clark's Nutcracker (Nucifraga columbiana), Eurasian Nutcracker (Nucifraga caryocatactes), and Gray Jay (Perisoreus canadensis). Dissertation, University of Lethbridge, Alberta, Canada. [online] URL: https://www.uleth.ca/dspace/handle/10133/4488? show $=$ full

Drummond, A. J., and R. R. Bouckaert. 2015. Bayesian evolutionary analysis with BEAST 2. Cambridge University Press, Cambridge, UK. http://dx.doi.org/10.1017/cbo9781139095112

Drummond, A. J., M. A. Suchard, D. Xie, and A. Rambaut. 2012. Bayesian phylogenetics with BEAUti and the BEAST 1.7. Molecular Biology and Evolution 29:1969-1973. http://dx.doi. org/10.1093/molbev/mss075

Environment Canada. 2014. Trend results for Gray-cheeked Thrush. Environment Canada, Gatineau, Quebec, Canada. [online] URL: http://www.ec.gc.ca/ron-bbs/P004/A001/?lang= e\&m $=$ s\&r=GCTH\&p=-

Excoffier, L., G. Laval, and S. Schneider. 2005. Arlequin ver. 3.0: An integrated software package for population genetics data analysis. Evolutionary Bioinformatics Online 1:47-50.

Godfrey, W. E. 1986. The birds of Canada. Revised edition. National Museums of Canada, Ottawa, Ontario, Canada.

Gosse, J., L. Hermanutz, B. McLaren, P. Deering and T. Knight. 2011. Degradation of boreal forests by nonnative herbivores in Newfoundland's national parks: recommendations for ecosystem restoration. Natural Areas Journal 31(4):331-339. http://dx.doi. org/10.3375/043.031.0403

Goudie, R. I. 1978. Red squirrels, Tamiasciurus hudsonicus, in the Salmonier River Valley, Newfoundland. Canadian FieldNaturalist 92:193-194.

Haché, S., E. M. Bayne, and M.-A. Villard. 2014. Postharvest regeneration, sciurid abundance, and postfledging survival and movements in an Ovenbird population. Condor 116:102-112. http://dx.doi.org/10.1650/CONDOR-13-002-R2.1

Hellmayr, C. E. 1934. Catalogue of the birds of the Americas, Part VII. Zoological Series Vol XIII, Field Museum of Natural History, Chicago, Illinois, USA.

Holder, K., R. Montgomerie, and V. L. Friesen. 2004. Genetic diversity and management of Nearctic Rock Ptarmigan (Lagopus mutus). Canadian Journal of Zoology 82:564-575. http://dx.doi. org/10.1139/z04-018

Hung, C.-M., S. V. Drovetski, and R. M. Zink. 2013. Recent allopatric divergence and niche evolution in a widespread Palearctic bird, the common rosefinch (Carpodacus erythrinus). Molecular Phylogenetics and Evolution 66:103-111. http://dx.doi. org/10.1016/j.ympev.2012.09.012

Jacobsen, F., N. R. Friedman, and K. E. Omland. 2010. Congruence between nuclear and mitochondrial DNA: combination of multiple nuclear introns resolves a well-supported phylogeny of New World orioles (Icterus). Molecular Phylogenetics and Evolution 56:419-427. http://dx.doi.org/10.1016/ j.ympev.2010.03.035

Jacques Whitford Environment. 1993. Avifaunal inventory, Gros Morne National Park. Report to Parks Canada, Rocky Harbor, Newfoundland, Canada.

Jaramillo-Correa, J. P., J. Beaulieu, and J. Bousquet. 2004. Variation in mitochondrial DNA reveals multiple distant glacial refugia in black spruce (Picea mariana), a transcontinental North American conifer. Molecular Ecology 13:2735-2747. http://dx. doi.org/10.1111/j.1365-294X.2004.02258.x

Kessel, B. 1998. Habitat characteristics of some passerine birds in western North America taiga. University of Alaska Press, Fairbanks, Alaska, USA.

Lait, L. A., and T. M. Burg. 2013. When east meets west: population structure of a high-latitude resident species, the boreal chickadee (Poecile hudsonicus). Heredity 111:321-329. http://dx. doi.org/10.1038/hdy.2013.54

Lamberton, R. D. 1976. Avifaunal survey of Gros Morne National Park. Parks Canada, Rocky Harbor, Newfoundland, Canada.

Lanfear, R., B. Calcott, S. Y. W. Ho, and S. Guindon. 2012. PartitionFinder: combined selection of partitioning schemes and substitution models for phylogenetic analyses. Molecular Biology and Evolution 29:1695-1701. http://dx.doi.org/10.1093/molbev/ $\mathrm{mss} 020$

Lele, S. R., M. Moreno, and E. Bayne. 2012. Dealing with detection error in site occupancy surveys: what can we do with a single survey? Journal of Plant Ecology 5:22-31. http://dx.doi. org/10.1093/jpe/rtr042

Leonard, T. D., P. D. Taylor, and I. G. Warkentin. 2008. Landscape structure and spatial scale affect space use by songbirds in naturally patchy and harvested boreal forests. Condor 110:467-481. http://dx.doi.org/10.1525/cond.2008.8512

Lerner, H. R. L., M. Meyer, H. F. James, M. Hofreiter, and R. C. Fleischer. 2011. Multilocus resolution of phylogeny and timescale in the extant adaptive radiation of Hawaiian Honeycreepers. Current Biology 21:1838-1844. http://dx.doi.org/10.1016/j. cub.2011.09.039

Lewis, K. P. 2004. Processes underlying nest predation by introduced red squirrels (Tamiasciurus hudsonicus) in the boreal forest of Newfoundland. Dissertation, Memorial University of Newfoundland, St. John's, Newfoundland, Canada.

Lewis, K. P., and B. M. Starzomski. 2015. Bird communities and vegetation associations across a treeline ecotone in the Mealy Mountains, Labrador, which is an understudied part of the boreal forest. Canadian Journal of Zoology 93:477-486. http://dx.doi. org/10.1139/cjz-2014-0309

Lowther, P. E., C. C. Rimmer, B. Kessel, S. L. Johnson, and W. G. Ellison. 2001. Gray-cheeked Thrush (Catharus minimus). In A. Poole, editor. The birds of North America online. Cornell Lab of Ornithology, Ithaca, New York, USA. http://dx.doi. org/10.2173/bna.591 
Marshall, J. T. 2001. The Gray-cheeked Thrush, Catharus minimus, and its New England subspecies, Bicknell's thrush, Catharus minimus bicknelli. No. 28. Nuttall Ornithological Club, Cambridge, Massachusetts, USA.

McFarland, K. P., C. C. Rimmer, S. J. K. Frey, S. D. Faccio, and B. B. Collins. 2008. Demography, ecology and conservation of Bicknell's Thrush in Vermont, with a special focus on the Northeast Highlands. Technical Report 08-03. Vermont Center for Ecostudies, Norwich, Vermont, USA. [online] URL: http:// m.vtecostudies.org/PDF/VCEBITHReport2008.pdf

Monroe, Jr., B. L., R. C. Banks, J. W. Fitzpatrick, T. R. Howell, N. K. Johnson, H. Ouellet, J. V. Remsen, and R. W. Storer. 1995. Fortieth supplement to the American Ornithologists' Union check-list of North American birds. Auk 112(3):819-830.

Montevecchi, W. A., and L. M. Tuck. 1987. Newfoundland birds: exploitation, study, conservation. No. 21. Nuttall Ornithological Club, Cambridge, Massachusetts, USA.

Ouellet, H. 1993. Bicknell's Thrush: taxonomic status and distribution. Wilson Bulletin 105:545-572.

Ouellet, H. 1996. Gray-cheeked Thrush. Pages 1170-1171 in J. Gauthier and Y. Aubry, editors. The breeding birds of Quebec: atlas of the breeding birds of southern Quebec. Association quebecoise des groupes d'ornithologues, Province of Quebec Society for the Protection of Birds, Canadian Wildlife Service, Environment Canada, Quebec Region, Montreal, Quebec, Canada.

Payne, N. 1976. Red squirrel introduction to Newfoundland. Canadian Field-Naturalist 90:60-64.

Peters, H. S., and T. D. Burleigh. 1951. The birds of Newfoundland. The Riverside Press, Cambridge, Massachusetts, USA.

Pielou, E. C. 1991. After the ice age: the return of life to glaciated North America. University of Chicago Press, Chicago, Illinois, USA. http://dx.doi.org/10.7208/chicago/9780226668093.001.0001

Prychitko, T. M., and W. S. Moore. 2003. Alignment and phylogenetic analysis of $\beta$-fibrinogen intron 7 sequences among avian orders reveal conserved regions within the intron. Molecular Biology and Evolution 20(5):762-771. http://dx.doi.org/10.1093/ molbev/msg080

Quebec Breeding Bird Atlas. 2016. Gray-cheeked Thrush observations. Quebec Breeding Bird Atlas, Quebec, Canada. [online] URL: http://www.atlas-oiseaux.qc.ca/donneesqc/cartes. jsp?lang=en

R Core Development Team. 2015. R: A language and environment for statistical computing. R Foundation for Statistical Computing, Vienna, Austria. [online] URL: http://www.R-project.org

Rae, L. F. 2014. Assessing the impacts of moose-induced habitat change on a forest bird community. Thesis, Memorial University of Newfoundland, St. John's, Newfoundland, USA.

Rae, L. F., D. M. Whitaker, and I. G. Warkentin. 2014. Multiscale impacts of forest degradation through browsing by hyperabundant moose (Alces alces) on songbird assemblages. Diversity and Distributions 20:382-395. http://dx.doi.org/10.1111/ ddi. 12133
Ralston, J., and J. J. Kirchman. 2012. Continent-scale genetic structure in a boreal forest migrant, the Blackpoll Warbler (Setophaga striata). Auk 129(3):467-478. http://dx.doi.org/10.1525/ auk.2012.11260

Rambaut, A., M. A. Suchard, D. Xie, and A. J. Drummond. 2014. Tracer v1.6. [online] URL: http://beast.bio.ed.ac.uk/Tracer

Ridgway, R. 1882. Description of two new thrushes from the United States. Proceedings of the U.S. National Museum Vol. IV:374-379. Washington, D.C., USA. http://dx.doi.org/10.5479/ si.00963801.240.374

Ridgway, R. 1907. The birds of North and Middle America, Part 4. Bulletin of the U.S. National Museum 50.

Rimmer, C. C., K. P. McFarland, W. G. Ellison, and J. E. Goetz. 2001. Bicknell's Thrush (Catharus bicknelli). In A. Poole, editor. The birds of North America online. Cornell Lab of Ornithology, Ithaca, New York, USA. http://dx.doi.org/10.2173/bna.592

Rogerson, R. J. 1983. Geological evolution. Pages 163-206 in R. South, editor. Biogeography and ecology of the island of Newfoundland. Springer, The Hague, The Netherlands.

Rozas, J., J. C. Sánchez-DelBarrio, X. Messeguer, and R. Rozas. 2003. DnaSP, DNA polymorphism analyses by the coalescent and other methods. Bioinformatics 19:2496-2497. http://dx.doi. org/10.1093/bioinformatics/btg359

Sauer, J. R, J. E. Hines, J. E. Fallon, K. L. Pardieck, D. J. Ziolkowski Jr., and W. A. Link. 2014. The North American breeding bird survey, results and analysis 1966 - 2013. Version 01.30.2015. USGS Patuxent Wildlife Research Center, Laurel, Maryland, USA.

Sauer, J. R., D. K. Niven, K. L. Pardieck, D. J. Ziolkowski Jr., and W. A. Link. 2017. Expanding the North American Breeding Bird Survey analysis to include additional species and regions. Journal of Fish and Wildlife Management, in press. http://dx.doi. org/10.3996/102015-jfwm-109

Shackleton, N. J., and N. D. Opdyke. 1976. Oxygen-isotope and paleomagnetic stratigraphy of Pacific core V28-239: late Pliocene to latest Pleistocene. Geological Society of America Memoirs 145:449-464. http://dx.doi.org/10.1130/MEM145-p449

Sólymos, P., M. Moreno, and S. R. Lele. 2016. Detect: analyzing wildlife data with detection error. $\mathrm{R}$ package Version 0.4. [online] URL: http://CRAN.R-project.org/package=detect

Sorenson, M. D., J. C. Ast, D. E. Dimcheff, T. Yuri, and D. P. Mindell. 1999. Primers for a PCR-based approach to mitochondrial genome sequencing in birds and other vertebrates. Molecular Phylogenetics and Evolution 12:105-114. http://dx.doi. org/10.1006/mpev.1998.0602

Species Status Advisory Committee (SSAC). 2010. The status of Gray-cheeked Thrush (Catharus minimus) in Newfoundland and Labrador. Report No. 24, Newfoundland and Labrador Species Status Advisory Committee, St. John's, Newfoundland, Canada. [online] URL: http://www.env.gov.nl.ca/env/wildlife/endangeredspecies/ ssac/Gray-cheeked_Thrush_2010_SSAC.pdf

Strong, J. S., and S. J. Leroux. 2014. Impact of non-native terrestrial mammals on the structure of the terrestrial mammal 
food web of Newfoundland, Canada. PLoS ONE 9(8):e106264. http://dx.doi.org/10.1371/journal.pone.0106264

Thompson, I. D., H. A. Hogan, and W. A. Montevecchi. 1999. Avian communities of mature balsam fir forests in Newfoundland: age-dependence and implications for timber harvesting. Condor 101:311-323. http://dx.doi.org/10.2307/1369994

Todd, W. E. C. 1963. Birds of the Labrador Peninsula, and adjacent areas: a distributional list. University of Toronto Press, Toronto, Ontario, Canada.

Topp, C. M., C. L. Pruett, K. G. McCracken, and K. Winker. 2013. How migratory thrushes conquered northern North America: a comparative phylogeography approach. PeerJ 1:e206. DOI10.7717/peerj.206 http://dx.doi.org/10.7717/peerj.206

van Els, P., C. Cicero, and J. Klicka. 2012. High latitudes and high genetic diversity: phylogeography of a widespread boreal bird, the Gray Jay (Perisoreus canadensis). Molecular Phylogenetics and Evolution 63:456-465. http://dx.doi.org/10.1016/j.ympev.2012.01.019

Vassallo, M. I., and J. C. Rice. 1981. Differential passerine density and diversity between Newfoundland and offshore Gull Island. Wilson Bulletin 93(3):340-349.

Wallace, G. J. 1939. Bicknell's thrush, its taxonomy, distribution, and life history. Proceedings of the Boston Society of Natural History 41:211-402.

Whitaker, D. M. 2015. The colonization of Newfoundland by Red Squirrels (Tamiasciurus hudsonicus). Osprey: Nature Journal of Newfoundland and Labrador 46:23-29.

Whitaker, D. M., P. D. Taylor, and I. G. Warkentin. 2015. Graycheeked Thrush (Catharus minimus minimus) distribution and habitat use in a montane forest landscape of western Newfoundland, Canada. Avian Conservation and Ecology 10(2):4. [online] URL: http://www.ace-eco.org/vol10/iss2/art4/

Winker, K., and C. L. Pruett. 2006. Seasonal migration, speciation, and morphological convergence in the genus Catharus (Turdidae). Auk 123:1052-1068. http://dx.doi.org/10.1642/0004-8038 (2006)123[1052:smsamc]2.0.co;2

Wulder, M., and T. Nelson. 2003. EOSD Land cover classification legend. Canadian Forest Service Natural Resources Canada, Pacific Forestry Centre, Victoria, British Columbia, USA.

Zink, R. M., and G. F. Barrowclough. 2008. Mitochondrial DNA under siege in avian phylogeography. Molecular Ecology 17:2107-2121. http://dx.doi.org/10.1111/j.1365-294X.2008.03737. 


\section{Appendix 1.}

Summary of Gray-cheeked Thrush tissues samples and surveys reported in: Taxonomy and distribution of the imperilled Newfoundland Graycheeked Thrush, Catharus minimus minimus

Alyssa M. FitzGerald, Darroch M. Whitaker, Joel Ralston, Jeremy J. Kirchman, and Ian G. Warkentin

Table A1.1. Summary of Gray-cheeked Thrush (Catharus minimus) tissue samples collected in Newfoundland and Labrador, Canada, as well as additional Gray-cheeked Thrush and Bicknell's Thrush (C. bicknelli) samples from elsewhere in Canada, the United States and Russia. Regional groups refer to those used in genetic comparisons within Gray-cheeked Thrush. The Hermit Thrush (C. guttatus) sample was used as an outgroup for coalescent analyses. GenBank sequence identification numbers may be accessed via www.ncbi.nlm.nih.gov/genbank/. However note that the sequences are being withheld on GenBank until May 1, 2018, to allow for publication of additional research by the authors.

\begin{tabular}{|c|c|c|c|c|c|c|c|}
\hline Regional group & Site & Year & Museum number ${ }^{\dagger}$ & $\operatorname{Sex}^{+}$ & $\begin{array}{l}\text { ND2 } \\
\text { GenBank } \\
\text { Accession } \\
\text { Number }\end{array}$ & $\begin{array}{l}\text { b-fib7 } \\
\text { GenBank } \\
\text { Accession } \\
\text { Number }\end{array}$ & $\begin{array}{l}\text { ADAMTS6 } \\
\text { GenBank } \\
\text { Accession } \\
\text { Number }\end{array}$ \\
\hline \multirow[t]{17}{*}{ Avalon (NF) } & Great Barasway & 2014 & NYSM zt-1209 & $\mathrm{U}$ & KY994675 & KY994874 & KY994807 \\
\hline & Great Barasway & 2014 & NYSM zt-1213 & $\mathrm{M}$ & KY994676 & KY994875 & KY994808 \\
\hline & Gull Island, Witless Bay Ecological Reserve & 2002 & NYSM zt-784 & M & KY994731 & & \\
\hline & Gull Island, Witless Bay Ecological Reserve & 2002 & NYSM zt-786 & M & KY994721 & & \\
\hline & Gull Island, Witless Bay Ecological Reserve & 2002 & NYSM zt-788 & $\mathrm{F}$ & KY994722 & & \\
\hline & Gull Island, Witless Bay Ecological Reserve & 2003 & NYSM zt-790 & $\mathrm{F}$ & KY994723 & & \\
\hline & Gull Island, Witless Bay Ecological Reserve & 2003 & NYSM zt-791 & M & KY994724 & & \\
\hline & Gull Island, Witless Bay Ecological Reserve & 2003 & NYSM zt-792 & M & KY994725 & & \\
\hline & Gull Island, Witless Bay Ecological Reserve & 2003 & NYSM zt-793 & $\mathrm{F}$ & KY994726 & & \\
\hline & La Manche Provincial Park & 2014 & NYSM zt-1207 & $\mathrm{U}$ & KY994673 & KY994873 & KY994805 \\
\hline & La Manche Provincial Park & 2014 & NYSM zt-1228 & M & KY994679 & & KY994809 \\
\hline & La Manche Provincial Park & 2014 & NYSM zt-1229 & M & KY994680 & & KY994810 \\
\hline & La Manche Provincial Park & 2014 & NYSM zt-1232 & $\mathrm{U}$ & KY994681 & & KY994811 \\
\hline & La Manche Provincial Park & 2014 & NYSM zt-1233 & M & KY994682 & & KY994812 \\
\hline & Patrick's Cove & 2014 & NYSM zt-1208 & M & KY994674 & & KY994806 \\
\hline & Patrick's Cove & 2014 & NYSM zt-1235 & $\mathrm{U}$ & KY994683 & & KY994813 \\
\hline & Patrick's Cove & 2014 & NYSM zt-1236 & $\mathrm{F}$ & KY994684 & & \\
\hline \multirow[t]{5}{*}{ Burgeo (NF) } & Big (Great) Island, Ramea & 2015 & NYSM zt-1170 & M & KY994656 & KY994860 & \\
\hline & Big (Great) Island, Ramea & 2015 & NYSM zt-1171 & M & KY994657 & KY994861 & \\
\hline & Big (Great) Island, Ramea & 2015 & NYSM zt-1172 & M & KY994658 & & \\
\hline & Burgeo & 2003 & NYSM zt-798 & M & KY994727 & & \\
\hline & Burnt Pond, Burgeo Road & 2015 & NYSM zt-1243 & M & KY994689 & & \\
\hline \multirow[t]{4}{*}{ Long Range Mts. (NF) } & Harding's Pond, Gros Morne National Park & 2014 & NYSM zt-1239 & $\mathrm{F}$ & KY994685 & & \\
\hline & Main River watershed & 2013 & NYSM zt-1183 & M & KY994661 & KY994864 & KY994793 \\
\hline & Main River watershed & 2013 & NYSM zt-1184 & M & KY994662 & KY994865 & KY994794 \\
\hline & Main River watershed & 2013 & NYSM zt-1186 & M & KY994663 & & KY994795 \\
\hline
\end{tabular}


Main River watershed

Main River watershed

Main River watershed

Main River watershed

Main River watershed

Main River watershed

N. Peninsula (NF)

$10 \mathrm{~km} \mathrm{~S}$ of Cook's Harbour

$10 \mathrm{~km} \mathrm{~S}$ of Cook's Harbour

$5 \mathrm{~km} \mathrm{~S}$ of Cook's Harbour

East shore, Pistolet Bay

Viking Trail, Sainte Lunaire

$3 \mathrm{~km} \mathrm{~W}$ of St. Lunaire

S. Labrador

$3 \mathrm{~km} \mathrm{~W}$ of St. Lunaire

$5 \mathrm{~km}$ NE of L'Anse-au-Loup

$5 \mathrm{~km}$ NE of L'Anse-au-Loup

$5 \mathrm{~km}$ NE of L'Anse-au-Loup

$5 \mathrm{~km}$ NE of L'Anse-au-Loup

$5 \mathrm{~km}$ NE of L'Anse-au-Loup

$5 \mathrm{~km}$ NE of L'Anse-au-Loup

$5 \mathrm{~km}$ NE of L'Anse-au-Loup

about $10 \mathrm{~km} \mathrm{~N}$. of Red Bay

about $10 \mathrm{~km} \mathrm{~N}$. of Red Bay

about $10 \mathrm{~km} \mathrm{~N}$. of Red Bay

Buckles Point Road, Forteau

Pinware

W. Labrador/ Quebec Brisay, Quebec

Brisay, Quebec

Miron River, Trans Labrador Hwy, Labrador

Miron River, Trans Labrador Hwy, Labrador

Orma Road, Churchill Falls, Labrador

Orma Road, Churchill Falls, Labrador

Orma Road, Churchill Falls, Labrador

Orma Road, Churchill Falls, Labrador

Orma Road, Churchill Falls, Labrador

Orma Road, Churchill Falls, Labrador

Orma Road, Churchill Falls, Labrador

Twin Falls Road, Labrador

Twin Falls Road, Labrador

Umiujaq, Nunavik, Quebec

Alaska
NYSM zt-1187

NYSM zt-1189

NYSM zt-1191

NYSM zt-1193

NYSM zt-1220

NYSM zt-1225

NYSM zt-1198

NYSM zt-1202

NYSM zt-1273

AMNH DOT-

AMNH DOT-

NYSM zt-1270

NYSM zt-1281

NYSM zt-1173

NYSM zt-1174

NYSM zt-1194

NYSM zt-1195

NYSM zt-1196

NYSM zt-1245

NYSM zt-1246

NYSM zt-1266

NYSM zt-1267

NYSM zt-1276

NYSM zt-1264

NYSM zt-1250

NYSM zt-778

NYSM zt-780

AMNH DOT-

AMNH DOT-

NYSM zt-1240

NYSM zt-1241

NYSM zt-1242

NYSM zt-1247

NYSM zt-1253

NYSM zt-1254

NYSM zt-1255

NYSM zt-1251

NYSM zt-1252

NYSM zt-782

UAM 13208

UAM 7596

UAM 8965

UAM 7440

UAM 7457

2000

AM 7458

UAM 14546
M KY994664

M KY994665

M KY994666

M KY994667

M KY994677

M KY994678

M KY994671

M KY994672

M KY994703

M KY994707

M KY994708

M KY994702

M KY994705

M KY994659

F KY994660

M KY994668

KY994669
KY994670

KY994690

KY994691

KY994700

KY994701

KY994704

KY994699

KY994693

KY994728

KY994729

KY994711

KY994706

KY994686

KY994687

KY994688

KY994692

KY994696

KY994697

KY994698

KY994694

KY994695

KY994730

KY994712

KY994717

KY994720

KY994714

KY994715

KY994716

KY994713
KY994866

KY994867

KY994871

KY994872

KY994884

KY994883

KY994886

KY994862

KY994863

KY994868

KY994869

KY994870

KY994882

KY994885

KY994796

KY994797

KY994798

KY994799

KY994803

KY994804

KY994825

KY994826

KY994800

KY994801

KY994802

KY994823

KY994824

KY994876 KY994814

KY994877 KY994815

KY994878 KY994816

KY994879 KY994817

KY994881 KY994820

KY994821

KY994880 KY994818

KY994819

KY994887 KY994822

KY994889 KY994830

KY994893 KY994834

KY994888 KY994827

KY994829 


\begin{tabular}{|c|c|c|c|c|c|c|c|}
\hline NA & Harbour Island, Halifax Co., Nova Scotia & 2010 & NYSM zt-1035 & $\mathrm{U}$ & KY994655 & KY994859 & KY994792 \\
\hline NA & Harbour Island, Halifax Co., Nova Scotia & 2010 & NYSM zt-952 & $\mathrm{U}$ & KY994710 & KY994894 & KY994835 \\
\hline NA & Markovo, Siberia, Russia & 2003 & UWBM 82277 & M & KY994718 & KY994890 & KY994831 \\
\hline NA & Markovo, Siberia, Russia & 2003 & UWBM 82290 & $\mathrm{~F}$ & KY994719 & KY994891 & KY994832 \\
\hline NA & Markovo, Siberia, Russia & 2003 & UWBM 82296 & M & KY994709 & KY994892 & KY994833 \\
\hline NA & 10 km N of Red Bay, Labrador ${ }^{\S}$ & 2015 & NYSM zt-1278 & M & KY994654 & KY994895 & \\
\hline \multirow[t]{30}{*}{ Bicknell's Thrush } & Hunter Mountain, Catskills, New York & 2009 & NYSM zt-924 & M & KY994739 & KY994855 & KY994778 \\
\hline & Twin Mountain, Catskills, New York & 2009 & NYSM zt-920 & M & & KY994854 & KY994777 \\
\hline & Phelps Mountain, Adirondacks, New York & 2008 & NYSM zt-577 & $\mathrm{U}$ & KY994738 & & KY994776 \\
\hline & Cascade Mountain, Adirondacks, New York & 2009 & NYSM zo-10928 & M & KY994743 & KY994839 & KY994764 \\
\hline & Cascade Mountain, Adirondacks, New York & 2009 & NYSM zo-10930 & M & KY994744 & & KY994765 \\
\hline & Cascade Mountain, Adirondacks, New York & 2011 & NYSM zo-11250 & M & KY994759 & KY994841 & KY994768 \\
\hline & Mount Mansfield, Lamoille Co., Vermont & 1993 & AMNH DOT- & M & KY994741 & KY994843 & KY994771 \\
\hline & Mount Mansfield, Lamoille Co., Vermont & 2012 & NYSM zt-1134 & M & KY994736 & KY994842 & KY994769 \\
\hline & Shrewsbury Peak, Rutland Co., Vermont & 1993 & AMNH DOT- & $\mathrm{F}$ & KY994742 & & KY994772 \\
\hline & Stratton Mountain, Windham Co., Vermont & 1999 & NYSM zo-14321 & $\mathrm{F}$ & KY994760 & & KY994774 \\
\hline & Stratton Mountain, Windham Co., Vermont & 2004 & NYSM zo-15341 & M & KY994746 & & KY994775 \\
\hline & East Mountain, Essex Co., Vermont & 2004 & NYSM zo-14313 & $\mathrm{F}$ & KY994745 & & KY994773 \\
\hline & Mount Coburn, Somerset Co., Maine & 2012 & NYSM zt-1106 & M & KY994734 & KY994840 & KY994766 \\
\hline & Mount Coburn, Somerset Co., Maine & 2013 & NYSM zt-1168 & M & KY994737 & & KY994770 \\
\hline & Redington Mountain, Franklin Co., Maine & 2012 & NYSM zt-1108 & $\mathrm{U}$ & KY994735 & & KY994767 \\
\hline & Massif du Sud, Bellechasse, Quebec & 2011 & NYSM zt-1481 & M & KY994754 & KY994850 & KY994787 \\
\hline & Massif du Sud, Bellechasse, Quebec & 2011 & NYSM zt-1482 & M & KY994755 & KY994851 & KY994788 \\
\hline & Lac Hermine, Réserve faunique des Laurentides, Quebec & 2012 & NYSM zt-1489 & M & KY994756 & KY994852 & KY994789 \\
\hline & Lac Becscie, Réserve faunique des Laurentides, Quebec & 2012 & NYSM zt-1490 & M & KY994757 & KY994858 & KY994790 \\
\hline & Lac Becscie, Réserve faunique des Laurentides, Quebec & 2012 & NYSM zt-1491 & M & KY994758 & KY994853 & KY994791 \\
\hline & Réserve faunique de Port-Cartier Sept-Iles, Quebec & 2006 & NYSM zt-1434 & M & KY994748 & KY994844 & KY994781 \\
\hline & Réserve faunique de Port-Cartier Sept-Iles, Quebec & 2006 & NYSM zt-1435 & M & KY994749 & KY994845 & KY994782 \\
\hline & Réserve faunique de Port-Cartier Sept-Iles, Quebec & 2006 & NYSM zt-1436 & M & KY994750 & KY994846 & KY994783 \\
\hline & Mount Edwards, New Brunswick & 2010 & NYSM zt1008 & M & KY994732 & KY994837 & KY994762 \\
\hline & Mount Edwards, New Brunswick & 2010 & NYSM zt1026 & M & KY994733 & KY994838 & KY994763 \\
\hline & Mine Madeleine, Gaspésie, Quebec & 2010 & NYSM zt-1476 & M & KY994751 & KY994847 & KY994784 \\
\hline & Mine Madeleine, Gaspésie, Quebec & 2010 & NYSM zt-1477 & M & KY994752 & KY994848 & KY994785 \\
\hline & Mine Madeleine, Gaspésie, Quebec & 2010 & NYSM zt-1479 & M & KY994753 & KY994849 & KY994786 \\
\hline & Money Point, Cape Breton, Nova Scotia & 2010 & NYSM zt-962 & M & KY994747 & KY994856 & KY994779 \\
\hline & Money Point, Cape Breton, Nova Scotia & 2010 & NYSM zt-964 & $\mathrm{F}$ & KY994740 & KY994857 & KY994780 \\
\hline Hermit Thrush & Main River watershed, Newfoundland & 2014 & NYSM zt-1223 & $\mathrm{M}$ & KY994761 & & KY994836 \\
\hline
\end{tabular}

${ }^{\dagger} \mathrm{AMNH}=$ American Museum of Natural History, NYSM = New York State Museum, UAM = University of Alaska Museum, UWBM = University of Washington Burke Museum.

$\$$ For sex: $\mathrm{M}=$ male, $\mathrm{F}=$ female, and $\mathrm{U}=$ unknown.

$\S$ This individual was excluded from analyses of regional groupings because it was found to carry a Bicknell's Thrush mtDNA haplotype. 


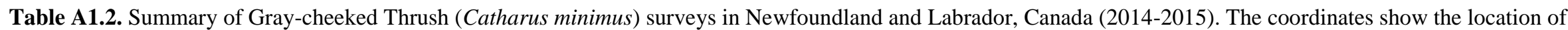
the first point count or, if no point count was conducted, the first vegetation survey.

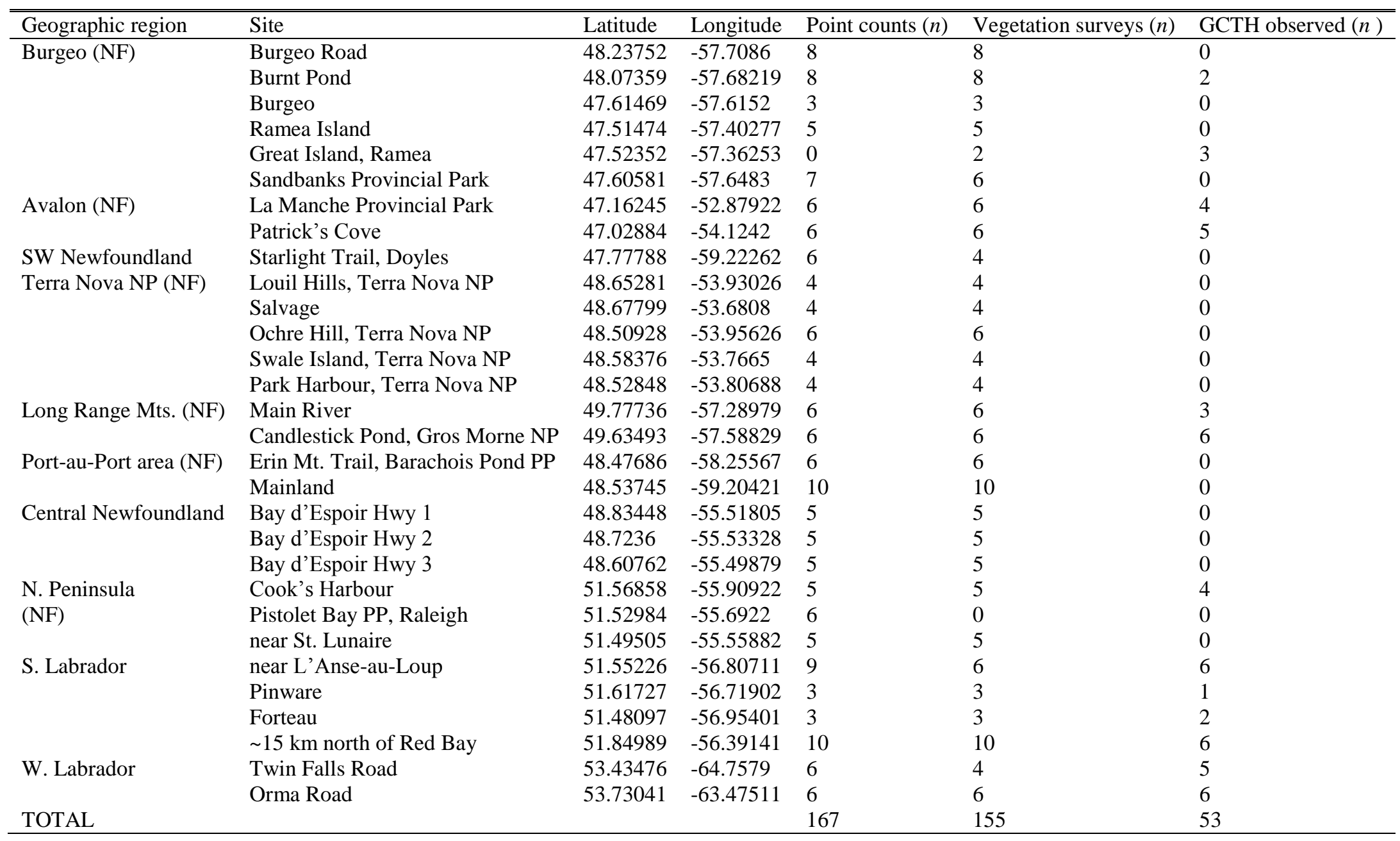

